\title{
Colette Moore, Quoting Speech in Early English, Cambridge University Press, Cambridge, 2014, 232 p.
}

\author{
Adina Chirilă ${ }^{*}$ \\ Facultatea de Litere, Istorie și Teologie, Universitatea de Vest, Bd. Vasile Pârvan 4, 300223 Timişoara, România
}

Cartea reprezintă un studiu amplu, din perspectivă lingvistică și literară/stilistică, asupra metodelor de marcare a discursului raportat în literatura din perioada premodernă a limbii engleze (1350-1600), avînd ca suport mai multe categorii de manuscrise și texte cuprinse în Corpus of Middle English Prose and Verse (CMEPV). Problema nu trebuie ignorată de către cercetarea diacronică a unei limbii întrucît de clarificarea planurilor discursului și a identității „,vocilor” care le creează depind, în general, editarea modernă corectă a unui text vechi, hermeneutica aplicată textului respectiv și concluziile privind aspectul limbii în epoci trecute, cu variațiile ei. Bunăoară, în opinia cercetătoarei Suzanne Romaine, profesor de limba engleză la Merton College, Oxford, înțelegerea faptului că "the norms for reporting speech in discourse or verse may have been different then [este avut în vedere în mod particular intervalul 15301550 din istoria limbii scoțiene-engl. Middle Scots, n.n.] or could have varied according to genre" (Romaine, 1982, p. 125) este fundamentală pentru emiterea unor ipoteze pertinente privind forma unei variante colocviale a limbii vechi, deoareceprecizează anterior autoarea- " $[\mathrm{e}] \mathrm{ven}$ if we examine quoted or indirect speech in prose or verse texts [...], which may be assumed to approximate speech to some extent, this is not speech" (ibidem).

Colette Moore preia speculația cercetătoarei britanice, pe care o evocă în capitolul Introduction: editing reported speech (p. 1), propunîndu-și, mai întîi, să identifice și să evidențieze practicile citării în Evul Mediu și, în al doilea rînd, să contureze relevanța stilistică a văditei inconsecvențe în utilizarea mărcilor discursului raportat și, de aici, a relativei neclarități în privința modului de expunere implicat la un moment dat: narațiune propriu-zisă, discurs direct (oratio recta) ori discurs indirect (oratio obliqua).

În amănunt, cercetarea pornește de la cîteva întrebări: în ce fel poate fi înțeleasă părerea că manuscrisele evidențiază modalități mai puțin clare și fixe de indicare a discursului raportat?; care erau concepțiile vorbitorilor și scriitorilor de limbă engleză din perioada premodernă despre discursul direct și indirect?; dacă și cum difereau acestea de ale vorbitorilor și scriitorilor actuali ?; ce urmări are aplicarea metodelor timpurii de marcare a discursului raportat asupra modului în care un cititor modern înțelege un text din Evul Mediu?; cum operau autorii medievali cu acest sistem fluid de marcare?; care sînt, în final, consecințele intruziunii practicii moderne de editare în privința acurateței cu care se transmite un text și este pus la dispoziție spre cercetare ulterioară? (p. 2). Căutîndu-le răspuns, Colette Moore îşi dezvoltă o metodă de lucru ce presupune îmbinarea perspectivelor lingvistică, pragmatică istorică și hermeneutică, posibile în scrutarea unui text.

Substanța cărții este cuprinsă în trei capitole ce surprind trei aspecte fundamentale ale citării în scrisul medieval, cu dezvoltările ideatice care se impun: modul de marcare a prezenței unui discurs raportat în text, cu precădere în manuscris (capitolul I, Methods of marking speech, p. 18-79); funcțiile citării și ale citatului în situații de comunicare diverse (capitolul II, Interpreting reported speech: defamation depositions, sermons, chronicles, p. 80-127); valorile stilistice ale vorbirii directe și indirecte într-un text medieval (capitolul III, Reported speech in literary texts: stylistic implications, p. 128-181).

Concluziile primului capitol se bazează, în principal, pe examinarea a șaisprezece manuscrise ale lucrării The Vision of Pierce the Plowman, atribuită prin dovezi interne lui William Langland (c. 1330-c. 1400) și care a supraviețuit prin mai mult de cincizeci de copii, în cel puțin trei variante; pe investigarea a douăzeci și trei de manuscrise ale operei lui Nicholas Love (?-c. 1424), The Mirror of the

*Adresă de corespondență: chiriladina@yahoo.com. 
Blessed Life of Jesus Christ, din cele şaizeci şi patru transmise pînă azi; și pe analiza unei serii editoriale privind un pasaj din Merchant's Tale (Geoffrey Chaucer, 1342-1400, Canterbury Tales), grupul de versuri 1263-1267, de la prima versiune tipărită, c. 1483 , de către William Caxton, pînă la ediția modernă din 1903 [1898], realizată de Alfred W. Pollard. Selecția operată de autoare este considerată reprezentativă pentru realizarea unui tablou al tehnicilor de marcare a discursului raportat utilizate de scribii epocii și, după introducerea tiparului, de editorii timpurii. Astfel, acestea apar diferențiate în două categorii: mijloace grafice, de mise-en-page, și mijloace lingvistice.

Primele manifestări de organizare grafică a paginii cu un conținut divers în ceea ce privește vocile implicate în construirea discursului includ: marca paragrafului (g); spațiul liber între rînduri; semne de punctuație: punctus (.), punctus elevatus (!) - acestea fiind întrebuințate în interiorul rîndului pentru a atrage atenţia asupra mărcii verbale (inquit) a citatului; rubricarea literelor (este cazul formei abreviate a verbului quod, de exemplu, sau al grafemelor inițiale ale rîndurilor cind acestea coincid cu replicile cuiva și al iniţialelor numelor proprii sau comune ce desemnează persoanele ale căror cuvinte sînt redate) ori a citatelor scripturale; sublinierea; note marginale, care atrag atenția nu doar asupra sursei citatului şi, implicit, asupra prezenței lui în text, ci, uneori, şi asupra gradului de acuratețe față de arhetip: citat abreviat de către compilator sau copist, parafrazare, deviere, augmentare.

Colette More precizează că, în general, asemenea metode nu sînt utilizate sistematic. Deși unele texte vădesc un grad mai mare de organizare a diferitelor mijloace de marcare a discursului raportat, cele mai multe dintre manuscrise sînt caracterizate, în această privință, de lipsă de claritate și constanță, cu frecvente alternări ale marcatorilor. De la un copist la altul, un anumit tip de marcă poate fi înlocuit cu altul, după obișnuințele și preferințele scribului. În alte situații, prezența unei mărci este complet ignorată atunci cînd, transcriind un text, copistul aplică o altă înţelegere conținutului acestuia, nesfiindu-se să „îmbunătățească” scriitura asupra căreia lucrează, din moment ce practica medievală a copierii permitea intervenția copistului ca interpret al textului.

Mijloacele lingvistice de indicare a alternării perspectivelor includ componente ale discursului, pre- cum interjecții, vocative, deictice pronominale și spațio-temporale, alți marcatori pragmatici etc., și meta-discursuri ori structuri incidente simple-cele mai frecvente fiind din categoria verba dicendi. În privința acestora, observîndu-le caracterul repetitiv și tendința de operare în perechi coordonate (d.e.: "Rolland ansuerd and sayd: syr guy of Bourgoyne, come ye..."-Charles the Grete, CMEPV, s.a., C.M., p. 58; "Charlemagne speke thus, he sayd to hym / I wyll that ye knowe $\mid$ now that I..."-Four Sons of Aymon, Caxton, CMEPV, s.a., C.M., p. 59), Colette Moore susține că ne aflăm mai degrabă în fața unui proces de pragmaticalizare/gramaticalizare, cel puțin în cazul unora dintre ele (i.e. engl. seien 'a spune'), în care verbul nu mai descrie evenimentul de a vorbi, ci îndeplinește o funcție textuală-aceea de a indica trecerea la vorbirea directă (deși, în deschiderea problemei, dublarea este recunoscută, în general, ca strategie stilistică frecventă în multe limbi pre-moderne şi în textul biblic, exemplificînd figura retorică copia).

Ideea gramaticalizării secvenței inquit este probată și de analiza funcțiilor formei adverbiale videlicet 'namely, clearly' (< lat. videre licet) în context juridic, corpusul examinat fiind alcătuit din o sută douăzeci de depoziții în cazuri de calomnie, înregistrate în perioada 1245-1645 în Anglia și Scoţia. Colette Moore constată că, în decursul secolelor, cunoscînd din ce în ce mai multe ocurențe de același tip, videlicet (și v., vi. sau viz.) își dezvoltă două funcții textuale: aceea de marcator al schimbării codului lingvistic (cînd textul juridic este redactat în latină și engleză, aceasta din urmă reprezentînd limba pe care o cunosc și o folosesc martorii în declarațiile lor) și aceea de marcator convențional al discursului raportat, fie vorbire directă, fie vorbire indirectă, ca în exemplul (23)/p. 64: "Durham Diocesan Records 1570. Elizabeth Robson contra Isabell knet knops in causa diffamacionis videlicet that she is a hoore $\&$ a harlott/".

În textele Evului Mediu așadar, secvențele inquit (cîteva verba dicendi și, într-un anumit tip de context, videlicet) îndeplinesc mai cu seamă un rol organizatoric în discurs, de obicei în lipsa altor mijloace învestite cu această funcție. Factorul care determină, la un moment dat, slăbirea acestei funcții pragmatice şi oprește gramaticalizarea totală a elementelor lexicale în chestiune, după Colette Moore, este apariția şi, cu timpul (după răspîndirea practicii multiplicării cărților prin tipărire), generalizarea altor convenții de 
editare: utilizarea caracterelor italice, a parantezelor (i.e. parentheses sau, după Erasmus, lunule, utilizate timp de trei secole pentru încadrarea secvenței inquit) și, mai apoi, a semnelor citării (i.e. diple, inverted comma).

Practica izolării secvenței inquit prin paranteze în preajma discursului raportat constituie pentru cercetătoare încă o dovadă în favoarea ideii că structuri precum he said ori quod she sînt semnificativ gramaticalizate, conținutul lor ideatic find minimal și indicat ca atare în economia discursului. Principalul argument teoretic în sprijinul acestei opinii este extras din cîteva manuale de întrebuințare a limbii engleze în scris, din secolul al XVI-lea, ale lui George Puttenham, Arte of English Poesie, 1589, Richard Mulcaster, Elementarie, 1582, și John Hart, An Orthographie, 1569 (care, de exemplu, caracterizează segmentul din paranteze ca dispensabil: "As the Parentheseos, which Gréeke word signifieth interposition: and we may understand to be a putting in, or an addition of some other matter by the way: which being left out yet the sentence remayneth good., p. 74).

În privinţa semnelor citării, Colette Moore scoate în evidență rolul pe care acestea l-au avut inițial (păstrat, de altfel, pînă la sfîrșitul secolului al XVIIlea), anume de a indica fragmente gnomice, sententia, al căror adevăr absolut este cunoscut ori, în opinia scribului sau a tipografului, trebuie să fie cunoscut şi acceptat de către cititori. Numai în mod secundar aceste semne (plasate, de regulă, la începutul pasajului gnomic ori pe marginea paginii, în dreptul fiecărui rînd cu un asemenea conținut) atrag atenția asupra prezenței unei anumite voci cu un aport oarecare la edificiul textului; funcția primară a lor este cea de invocare a unei autorități (auctoritas) bazate nu pe ideea de proprietate intelectuală, ci pe cea de adevăr al celor spuse.

Capitolul al doilea analizează trei genuri de texte (depoziții, predici și cronici istorice), pentru a identifica și descrie concepțiile autorilor și scribilor cu privire la actul citării, modul în care acestea operează în texte, în funcție de gen, și rolul discursului raportat în construirea întregului. În cadrul consemnării scrise a desfășurării proceselor de calomnie, problema privește acuratețea redării depoziţiilor. Colette Moore constată că uzanțele epocii permit nu numai transformarea ad hoc a vorbirii directe a martorilor în vorbire indirectă, păstrîndu-se totuși imaginea $d e$ dicto a discursului, acceptîndu-se de la sine ideea că, în proces, cuvintele au fost reproduse așa cum au fost rostite, ci și consemnări de re, în care afirmațiile sînt reproduse în conformitate cu judecata aplicată de către grefier. Convenția dă prioritate loialităţii față de standardele legale (în privința limbajului), în defavoarea consemnării exacte (verbatim) a mărturiilor.

Investigația se oprește apoi asupra predicilor din pricina importanței cruciale pe care o exercită citarea surselor biblice și patristice în demonstrarea legitimităţii unei afirmaţii a oratorului religios. Considerînd că citarea cu finalitate probatorie este, prin excelență, o particularitate a predicii scolasticespecie a retoricii de amvon dezvoltată în Europa occidentală începînd cu ultimele decenii ale secolului al XII-lea-, Colette Moore examinează un corpus de peste o sută cincizeci de predici de acest tip. În general, se constată o relație ambiguă între predicator și citarea surselor. Atribuirea unui fragment se face adeseori imprecis, fapt ce poate $f i$ un indiciu al valorii pragmatice a actului indicării unei voci autoritare, cînd nu se manifestă putința de a identifica indubitabil acea voce ori în absența dorinței de a o identifica, atunci cînd oratorul pune pe seama altcuiva propriile comentarii. Fragmentele desemnate ca citate apar mai mult sau mai puţin neloiale față de arhetip, devierile concretizîndu-se în combinarea tacită a mai multor surse (Moore oferă exemplul predicii a doua din colecția British Library MS Royal 18 B. xxiii, care începe cu mai multe fragmente biblice-In, 6, 57, Mt, 12, 44, Lc, 11, 24tratate ca pasaj unitar), rezumarea, inserarea liberă şi nemarcată a comentariilor oratorului în cuprinsul segmentului citat, extrapolarea, tranziţia abruptă de la latină la engleză și de la vorbire directă la vorbire indirectă, redarea bilingvă, redundantă a pasajului vizat etc. Cîteva situații pun în evidență și o altă problemă specifică perioadei premoderne a unei limbi vernaculare, în circumstanțe istorice și culturale specifice: relația dintre textul-sursă redactat într-o limbă sacră (i.e. latina) și traducerea efectuată în limba vernaculară (i.e. engleza), cercetătoarea opinînd că " $[$ s]ince most of the quotations are from Latin source material, investigating the conception of faithfulness in quotation entails investigating the conception of faithfulness in translation" (p. 106). Privind textele din această perspectivă, Colette Moore constată că, în condițiile unei perioade de cenzură și de represiune a redărilor vernaculare ale Scripturii în cuprinsul ori- 
căror forme literare-libri, libelli, aut tractatus (fapt stipulat prin Articolul 7 din Constituţia Episcopului Arundel, din 1407-1409), oratorii au fost nevoiți fie să păstreze în limba latină pericopele utilizate în predicile lor, fie să realizeze ei înșiși traduceri foarte servile, care urmăreau litera originalului și ignorau resursele limbii engleze de a reda spiritul acestuia (demonstrate deja prin Biblia lui John Wycliffe), fie să creeze parafraze, astfel încît cenzorii să nu mai perceapă în lucrarea suspectă prezența unui citat, ci a unei interpretări.

Abordînd cronici istorice din perioada 13501500 (Brut - The Chronicles of England, Polychronicon - traducerea cu adnotările lui John Trevisa, The Chronicle of Popes and Emperors, Lollard Chronicle etc.), gen care se întemeiază, parțial, prin raportare de discurs, cercetătoarea atrage atenția în mod special asupra caracterului convențional-retoric al raportării discursului direct: actul „citării” vorbirii directe a unei figuri istorice trebuie interpretat ca actul unei aproximări, al creării de către cronicar a unui discurs plauzibil și semnificativ în contextul politic ori dramatic în care acționează personajele. Motivul apariției acestui tip de raportare discursivă este unul retoric, stimulat de firul narativ şi mai puțin de impulsul de a întări ideea de acuratețe (p. 117). O altă observație se referă la modul fluid în care narațiunea, metacomentariul asupra discursului direct și vorbirea apar în alcătuirea cronicii, cu treceri nemarcate ori nesigure, din punctul de vedere al editorului modern, de la un mod de expunere la altul.

În capitolul al treilea, Colette Moore analizează operele a trei scriitori canonici din secolul al XIVlea: anonimul și prezumtivul unic creator al poemelor Pearl, Cleanness, Patience și Sir Gawain and the Green Knight (British Library, Ms Cotton Nero A.x), William Langland (The Vision of Piers the Plowman) și Geoffrey Chaucer (Canterbury Tales), argumentînd că unii dintre autorii Evului Mediu tîrziu utilizează sistemul de marcare a discursului raportat într-un mod care creează ambiguitate, deci posibilitatea unei lecturi multiple a textului, intrinsecă proiectului literar (p. 132). Așa stînd lucrurile, urmează că opțiunea editorului modern în privința configurației aparatului suplimentar ce ar indica fără echivoc secvențele discursului raportat din textul literar vechi reflectă o decizie interpretativă singularizatoare, care dezavantajează textul. Un asemenea demers anacronic ar fi inutil într-un caz ca cel al pasajului cunoscut drept „elogiul căsătoriei” ("the Marriage Encomium"), din textul The Merchant's Tale al lui Chaucer, desfășurat între versurile 1267 și 1392: autoarea este de părere că lipsa de claritate în privinţa identității vocilor care îl compun este cheia interpretării juste a elogiului ca o succesiune de adevăruri generale pe tema căsătoriei-de sententic al căror conținut aparține întregii umanități-, în acord cu maniera și rostul introducerii citatelor sapiențiale în predici (p. 176-177). În altă parte-The Vision of Piers the Plowman-, afirmă Colette Moore, obscuritatea este esențială în recrearea pentru cititor a experienței onirice descrise în poem şi în împlinirea scopurilor didactice ale acestuia: "[a]s constructed by indeterminacies in voices and speakers, Will's journey is partly a journey of perspective, as seemingly external concepts and ideas are internalized and become part of his own thinking. As readers, we undergo this journey with him." (p. 162).

Numeroasele fragmente aduse în discuție în capitolele al doilea și al treilea ale cărții și perspectivele din care sînt comentate conduc spre concluzia că, pentru a i se acorda cititorului de azi posibilitatea de a vedea modalitățile subtile în care scriitorii vechi utilizau sisteme de marcare a discursului raportat și, prin urmare, șansa de a ajunge la o înțelegere mai adîncă a artei literare medievale, este esențială aplicarea prudentă şi cu discernămînt, în asemenea texte, a normelor editoriale moderne în privința citării.

Evaluare. Cartea a fost bine primită de comunitatea academică internațională, fiind recenzată favorabil la puțină vreme după apariția primei ediții. Petré (2012) aprecia de la bun început că este, în general, bine scrisă și accesibilă unui public larg, o însemnată contribuție în domeniul filologiei engleze și al studiilor literare medievale.

Specialist ori nu, cititorul descoperă o lucrare bine închegată, în care argumentarea se sprijină atît pe dezvoltări teoretice ale unor concepte, reprezentate de studii fundamentale devenite clasice (i se poate reproșa însă rămînerea la acestea, v. Petré, 2012, p. 304), cît și pe cercetări empirice, în mare parte personale. În privința studiului aplicat, Colette Moore este pe cont propriu în primul capitol, cînd, în urma examinării textelor, realizează tabele sinoptice originale privind mărcile discursului raportat, în Troilus and Criseyde (Geoffrey Chaucer) și The Regiment of Princes (Thomas Hoccleve), și funcțiile 
pragmatice ale verbelor dicendi și ale lui videlicet, în literatura perioadei. Punctul de vedere susținut aici în legătură cu (pre)gramaticalizarea verbului citațional seien este, cu siguranță, interesant, dar argumentele nu sînt pe de-a-ntregul convingătoare. Surprinde, în primul rînd, necorelarea presupusului proces de gramaticalizare a lui seien ca marcă a citării, în limba engleză, cu procesul de gramaticalizare a aceluiași verb citațional ca element complementarizator, fenomen descris de Deutcher (2000), la care Hopper \& Closs Traugott (2003) fac referire după ce apreciază, în legătură cu limba engleză, că “[it] is often thought that a special subset of complementation structures, quotatives in which someone else's speech is reported, arose out of simple juxtaposition of ' $\mathrm{X}$ say/said' followed by the quotation [...], but there has been little direct historical evidence for such development" (p. 194; v. și urm.). În al doilea rînd, indiferent de rezultatul prezumtiv al gramaticalizării lui seien (presupunînd că se poate vorbi de rezultate diferite aici: indice al citării sau conector), nu se emite o ipoteză asupra stadiului de gramaticalizare atins; autoarea vorbește despre un moment în care complexul proces este oprit, însă demonstrația existenței unui parcurs înspre polul funcțional al unui continuum lexical-funcțional (Haspelmath, 1999, p. 1044) se întemeiază (cf. cele șase criterii ale gramaticalizării, Lehmann, 2002, p. 108-159) numai pe ceea ce apare ca estompare a sensului-observație ce ar corespunde unei diminuări a parametrului integrității (semantice), din teoria lui Lehmann, 2002, p. 114)—, fără problematizările ulterioare necesare.

În cuprinsul capitolului al doilea sînt implicate frecvent deciziile editoriale și observațiile filologilor care s-au ocupat de editarea științifică a textelor medievale engleze, fapt ce dă acestei părți a cărții o notă de sinteză bibliografică, firească și utilă, de altfel, în urmărirea obiectivelor menționate la începutul capitolului.
Etalînd subtilitatea și spiritul critic al cercetătoarei față de interpretări literare anterioare, analiza din capitolul al treilea este convingătoare cînd propune lecturi şi înţelegeri noi ale pasajelor excerptate și reușește să scoată în evidență implicaţiile stilistice ale ambiguității în modul în care discursul raportat apare în construirea textelor. $\mathrm{Nu}$ este tranșant rezolvată însă problema cauzei primare a acestei neclarităţi: alegerea deliberată a autorilor în privința unor tebnici stilistice de alternare, întrepătrundere și suprapunere a vorbirii directe și indirecte (cf. Petré, 2012, p. 305) sau stadiul incipient de elaborare a normelor citării, în epocă. Autoarea sugerează ambele posibilități: "most writers of the late medieval period use the systems of speech marking only to set off the represented discourse in their texts as clearly as they deemed necessary, and not with an eye to any particular effect. Nevertheless, [...] indeterminacy as to the speaker or to the boundaries of the speech creates a significant double reading. [...] this double reading, if not demonstrably intentional, is nonetheless intrinsic to the literary project" (p. 132); dar și: “[t] his voice shifting is a stylistic technique that the poet employs to emphasize semantic shifts and it is made possible by the less-determined system of speech marking" (p. 144).

Se dovedesc utile în structura cărții un apendix ce conține fotocopii a două fragmente din manuscrisele lucrării The Vision of Piers the Plowman, pentru familiarizarea cititorului cu maniera medievală de folosire a semnelor grafice în raportarea discursului, un apendix cu siglele manuscriselor analizate și un indice tematic și de nume.

Noutatea ideilor prezentate și calitatea argumentației teoretice și empirice desfăşurate de Colette Moore impun cartea ca sursă bibliografică de neignorat pentru viitoare studii de lingvistică diacronică și stilistică, nu numai în spațiul anglosaxon.

\section{Bibliografie}

Deutcher, G. (2000). Syntactic Change in Akkadian: the Evolution of Sentential Complementation, New York: Oxford University Press. Haspelmath, M. (1999). Why is grammaticalization irreversible, în "Linguistics", 37 (6), p. 1043-1068, CrossRef.

Hopper, P.J. \& Closs Traugott, E. (2003). Grammaticalization, Cambridge University Press, CrossRef.

Lehmann, Chr. (2002). Thoughts on grammaticalization. Second, revised edition, în "Arbeitspapiere des Seminars für Sprachwissenschaft der Universität Erfurt", nr. 9, iulie.

Petré, P. (2012). Recenzie la Colette Moore, Quoting Speech in Early English. 2011. Cambridge: Cambridge University Press, în "English Text Construction" 5 (2), p. 300-306, CrossRef.

Romaine, S. (1982). Socio-Historical Linguistics. Its Status and Methodology, Cambridge: Cambridge University Press, CrossRef. 